
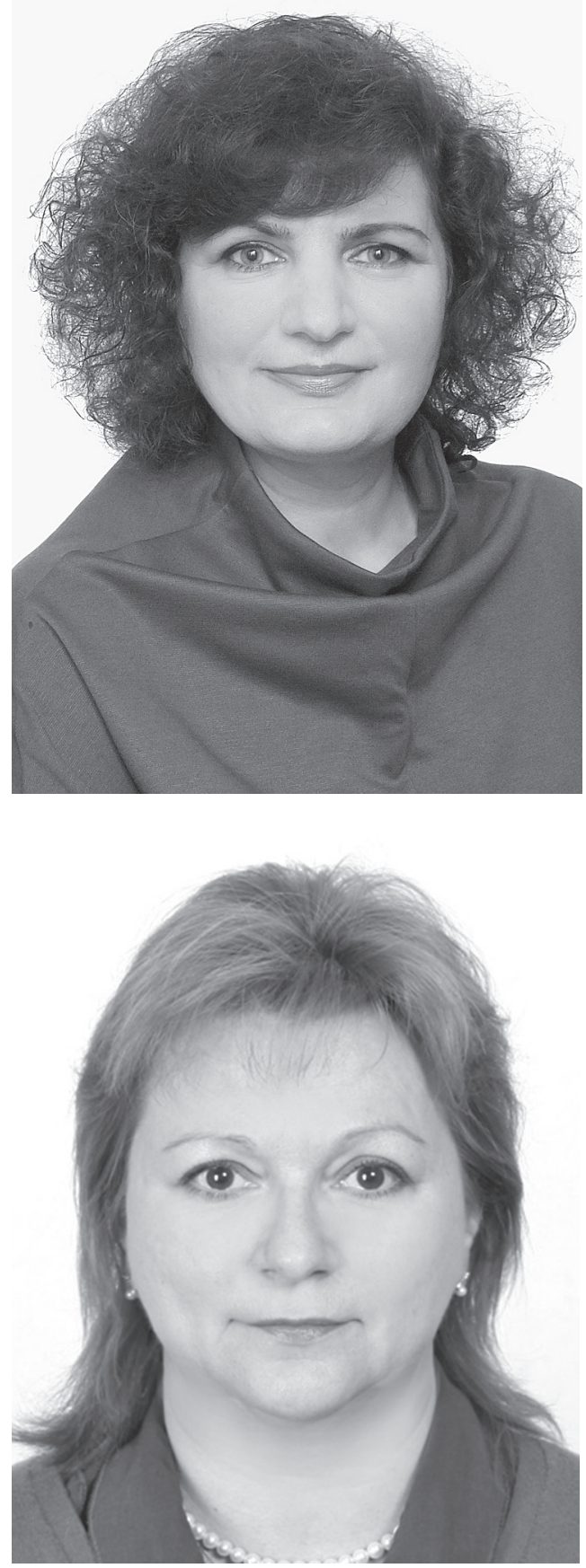
сультант народного депутата України, Верховна Рада України, 01005, м. Київ, вул. Грушевського, 5, тел.: + 38 (050) 39722 91, e-mail: maria.lashkina@gmail.com ORCID: 0000-0002-8331-1853

\section{Bielska Tetiana Valentyniona,}

Doctor of Science in Public Administration, Associate Professor of the Department of Management and Administration, O. M. Beketov National University of Urban Economy in Kharkiv, 61002, Kharkiv, Str. Marshala Bazhanova, 17, tel.: + 38 (066) 45062 12,e-mail: tanya_belska@ukr.net

ORCID: 0000-0002-2792-4700

\section{Бєльська Тетяна Валентинівна,} доктор наук з державного управління, доцент кафедри менеджменту $i$ адміністрування, Харківський національний університет міського господарства імені О. М. Бекетова, 61002, м. Харків, вул. Маршала Бажанова, 17, тел.: + 38 (066) 45062 12,e-mail:tanya_belska@ ukr.net

$$
\text { ORCID: 0000-0002-2792-4700 }
$$

\section{Бельская Татьяна Валентиновна,}

доктор наук по государственному управлению, доцент кафедры менеджмента и администрирования, Харьковский наииональный университет городского хозяйства имени А. Н. Бекетова, 61002, 2. Харьков, ул. Маршала Бажанова, 17, тел.: + 38 (066) 45062 12, e-mail: tanya_ belska@ukr.net

ORCID: 0000-0002-2792-4700

\section{Lashkina Mariia Hryhoriona,}

psychologist-conflictologist, PhD in Public Administration, Assistant-consultant of People Deputy of Ukraine, Verkhovna Rada of Ukraine, 01005, Kyiv, Str. Hrushevskoho, 5, tel.: + 38 (050) 39722 91, e-mail: maria. lashkina@gmail.com

$$
\text { ORCID: 0000-0002-8331-1853 }
$$

\section{Лашкіна Марія Григорівна,}

психолог-конфліктолог, кандидат наук

з державного управління, помічник-кон- 
Лашкина Мария Григорвевна,

психолог-конфликтолог, кандидат наук по государственному управлению, помощник-консультант народного депутата Украины, Верховная Рада Украины, 01005, г. Киев, ул. Грушевского, 5, тел.: + 38 (050) 39722 91, e-mail: maria.lashkina@ gmail.com

\title{
THE COUNTRIES OF TRANSITION DEMOCRACY IN THE PROCESS OF DEMOCRATIC TRANSIT: AN ARCHETYPAL ASPECT
}

\begin{abstract}
The authors offer non-standard views on the processes of establishing democracy in developing countries. In the article the processes of democratic transit by using archetypal methodology are analyzed; the processes of the influence of archetypes on democratic institutions in the conditions of information society and technological revolution are considered. The laws and conditions of the formation or destruction of state institutions in transition democracies, their hybridity, partially authoritarian hierarchy or chaos, and uncertainty of progress towards the goal are determined. The authors, by using of the methodology of E. Dyurgeym - imposition of biological methods of research on social processes, metaphorically compare the stages of personality development and the processes of state formation and conclude that the Ukrainian state is now in the stage of individualization and understanding itself. The structure of personality according to K. Jung is considered, its main components are distinguished. The authors suggest that in countries that have recently embarked on a path of democracy, the connection between rational and irrational is stronger than in countries that are entrenched in established democracies. These processes are metaphorically compared by the authors with the connection of the conscious and unconscious in the formation of the individual. They come to the conclusion that the lack of archetypal subconscious nature and code of culture and national codes of democratic values creates obstacles to their formation in the public consciousness. This is reflected in the socio-political activity of the state and in the functionality of its institutions. In the information society, the vector of the influence of archetypes on democratic social institutions, which leads to a hybrid distortion of the concept of the state as a device of violence and pressure, has changed. Postcommunist transformations represent a new wave, but the trajectories and outcomes of postcommunist transformations are different for states, so democratic transit is uneven.
\end{abstract}

Keywords: archetype, democratic transit, hybrid regimes, civil society, chaos, self-organization. 


\section{КРАЇНИ ПЕРЕХІДНОЇ ДЕМОКРАТІЇ В ХОДІ ДЕМОКРАТИЧНОГО ТРАНЗИТУ: АРХЕТИПНИЙ АСПЕКТ}

Анотація. Автори пропонують нестандартні погляди на процеси становлення демократії в країнах, що розвиваються. Аналізуються процеси демократичного транзиту із застосуванням архетипної методології; розглядаються процеси впливу архетипів на демократичні інститути в умовах інформаційного суспільства та технологічної революції. Визначено закономірності й умови формування чи руйнування інститутів держави в країнах перехідної демократії, їх гібридність, частково авторитарна ієрархізація або хаотичність й невпевненість просування до мети. Автори, використовуючи методологію Е. Дюркгейма - накладення біологічних методів дослідження на соціальні процеси, метафорично порівнюють стадії розвитку особистості та процеси формування держави й роблять висновок, що Українська держава зараз перебуває у стадії індивідуалізації, розуміння себе. Розглядається структура особистості за К. Юнгом, виділяються основні їі складові. Автори припускають, що в країнах, які нещодавно стали на шлях демократії, зв’язок раціонального й ірраціонального є сильнішим, ніж у країнах, що закріпилися в усталених демократіях. Ці процеси метафорично порівнюють зі зв’язком свідомого й несвідомого у формуванні особистості. Вони приходять до висновку, що відсутність в архетиповій підсвідомій природі та коді культури й національних кодах демократичних цінностей створює перешкоди на шляху їх формування в суспільній свідомості. Це відображається і на соціально-політичній діяльності держави, і на функціональності їі інститутів. В інформаційному суспільстві змінився вектор впливу архетипів на демократичні соціальні інститути, що призводить до гібридного викривлення поняття держави як апарату насильства й тиску. Посткомуністичні трансформації являють собою нову хвилю, однак траєкторії та результати посткомуністичних трансформацій є різними для держав, тому демократичний транзит відбувається нерівномірно.

Ключові слова: архетип, демократичний транзит, гібридні режими, громадянське суспільство, хаос, самоорганізація.

\section{СТРАНЫ ПЕРЕХОДНОЙ ДЕМОКРАТИИ В ПРОЦЕССЕ ДЕМОКРАТИЧЕСКОГО ТРАНЗИТА: АРХЕТИПНЫЙ АСПЕКТ}

Аннотация. Авторы предлагают нестандартные взгляды на процессы становления демократии в развивающихся странах. Анализируются процессы демократического транзита с применением архетипной методологии; рассматриваются процессы влияния архетипов на демократические институты в условиях информационного общества и технологической революции. Определены закономерности и условия формирования или разрушения институтов государства в странах переходной демократии, их гибридности, частично авторитарная иерархизация или хаотичность и неуверенность продвижения к цели. Авторы, используя методологию Э. Дюркгейма - наложение биоло- 
гических методов исследования на социальные процессы, метафорически сравнивают стадии развития личности и процессы формирования государства и делают вывод, что Украинское государство сейчас находится на стадии индивидуализации, понимания себя. Рассматривается структура личности по К. Юнгу, выделяются основные ее составляющие. Авторы предполагают, что в странах, которые недавно стали на путь демократии, связь рационального и иррационального является более сильной, чем в странах, где закрепились в устоявшихся демократиях. Эти процессы авторы метафорически сравнивают со связью сознательного и бессознательного в формировании личности. Они приходят к выводу, что отсутствие в архетипической подсознательной природе, в коде культуры и национальных кодах демократических ценностей создает препятствия на пути их формирования в общественном сознании. Это отражается и на социально-политической деятельности государства, и на функциональности ее институтов. В информационном обществе изменился вектор влияния архетипов на демократические социальные институты, это приводит к гибридному искривлению понятия государства как аппарата насилия и принуждения. Посткоммунистические трансформации представляют собой новую волну, однако траектории и результаты посткоммунистических трансформаций различны для государств, поэтому демократический транзит происходит неравномерно.

Ключевые слова: архетип, демократический транзит, гибридные режимы, гражданское общество, хаос, самоорганизация.

"Consciousness is a bad judge for what happens in the depths of being because it does not penetrate there"

David Emil Durkheim - a French sociologist and philosopher.

Problem statement. The modern world becomes more and more unpredictable and changeable. The development of technologies, scientific discoveries, new opportunities for social researches and influences change approaches to the treatment of politics, ideologies, and moral imperatives. The desacralization of power, institutions, personalities, professions and specialties, which has become a new global phenomenon as a result of the impact of technology development and the creation of social networks, raises concerns about the sustainability of democratic regimes from academics, experts and politicians around the world.

The state of societies that consume more information products and are in a continuous nervous and stress state due to the inability to process and digest a huge amount of communicative influences increasingly depends on the psycho-emotional state of the masses 
and the main players on the political arenas that are responsible for decisionmaking. It can be stated that this state of uncertainty is typical for most of transformational countries. Ukraine is not a unique element of the world political system; its psycho-emotional state is still being tested by military actions, which have been going on for four years. The institutions in which democracy is held depend on the human factor today more than ten or twenty years ago. It is important to understand all influences and processes that take place in the psychosocial sphere of society; therefore our view on transformational regimes through archetypal methodologies is very relevant.

Analysis of recent publications emphasizes the multidisciplinary view on the problem and gives us the opportunity to rely on the theoretical work of various fields of knowledge and scientific schools, in particular: the analytical psychology of $\mathrm{K}$. Jung, his successors - Maria-Louise von Franz, D. Sharp, and others; french school of sociology of everyday life - M. Maffesoli, J. Bordiyar, G. Lebona, G. Tarda, E. Durkheim, S. Moskovichi and others; the concept of the ethnocultural division of civilizations of S. Huntington; political science views of A. Brown, T. Charles, and F. Schmitter. Among the contemporary Ukrainian scholars, we can note the work of the authors of the Ukrainian school of archetype: E. Afonin, O. Donchenko, and A. Martynov. And also Ukrainian researchers in the field of public administration: R. Voitovich, V. Kazakov, M. Piren, and others.

Determination of previously unsolved parts of the general problem lies in the conditioned development of high technological information transition, which exacerbated manifestations of the emotional and intuitive nature of the person that were persistently squeezed by the rationality of the industrial society. This becomes a threat to the existence of democratic institutions, even in developed and strong countries, and for transformation, it is threatened by hybridity of regimes and lagging behind. The influence of archetypes on transformational regimes, their interdependence did not have a clear conceptual study.

The purpose of the article is the authors' attempt to comprehend the mutual influence of archetypes and institutions in the conditions of democracy and the information society and technological revolution in developing countries; regularities and conditions of formation or destruction of state institutions in transition democracies, their hybridity, the partial authoritarian hierarchy or chaos, and the uncertainty of progress towards the goal.

Statement of the main research material. In conditions of variability and uncertainty of the modern world, archetypical methodology allows us to find out regularities by analyzing tendencies and randomness, and make unordinary conclusions. The phenomenon of archetype, as characterized by Ukrainian sociologist O. Donchenko, is not connected with the state as a managerial structure and is capable to penetrate into an autonomous (nonstate) way of life, an out-of-state model that constantly mobilizes the collective spirit. There are vertical and horizontal archetypes, archetypes of economic and cultural life, mobilization arche- 
types, which in one way or another also affects the socio-economic and political processes in the country and the elite [1, p. 158].

Among the large number of archetypes that were analyzed and described by representatives of the Jungian School of Analytical Psychology, is the matrix archetype of integrity, called "uroboros" (from the ancient Greek

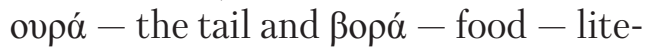
rally "the one that eats its tail"), visualized in the form of an ancient symbol of a snake that eats its tail. In analytical psychology, this archetype symbolizes darkness and self-destruction simultaneously with fertility and creative potential. At the same time, E. Neumann defines and analyzes this archetype as an early stage in the development of personality [2]. It symbolizes the constancy of the basis on which the person holds. By using of the methodology of E. Durkheim on the imposition of biological research methods on social processes, we can metaphorically compare the stages of personality development and the processes of state formation. If to apply them to processes in Ukraine, we can state that the state is now in the stage of individualization, understanding itself.

O. Donchenko expands the content of the matrix archetype and offers its interpretation as a given, that requires, on the one hand, the availability of diversity, and on the other - the refusal of any conflicting among themselves socio-political interpretations of formations, the establishment of relations between them tolerance and mutual needs [3 , p. 158].

In fact, this archetype gives an understanding of the presence in the so- cietal psyche as processes of destruction, as well as the development and creation of new ways of life. Archetypes are a part of the spiritual life of the nation and they manifest in the period of creative activity. S. Sibiryakov conditionally divided archetypes into three groups: universal - immutable, ethno cultural - weakly changing and cultural - changeable [4, p. 202]. The archetype "uroboros" can be attributed to the universal one, that is, the root cause, of which everything was born. It includes chaos, self-organization, all inherent in the complex dynamic structure of quality.

The modern world of human life becomes more chaotic, unpredictable and conflicting, with uncertain composition of values, the state is inherent in many states, including Ukraine. K. Jung compared archetypes with apriority instincts, common with animals, so close, that they manifest their unconscious images, in other words, are "models of instinctive behavior". Typically, these models are embodied in the mythological national consciousness. Archetype - an independent area of the psyche, its unconscious part, therefore, is very vulnerable in the information world, which has strong mechanisms of psychological influence.

According to K. Jung the structure of the personality includes conscious, unconscious and collective unconscious. The collective unconscious is filled with the memory of ancestors, traditions, rituals, and the heritage of all mankind, reflected in the individual archetype of each person.

Consciousness is "a person" and "ego," roles that are full by symbols, myths, personal and social duties and 
thoughts, emotions, and ideas that fill it. The archetype of the "shadow," as defined by $\mathrm{K}$. Jung, is a subconscious hidden essence, which is sometimes difficult and not very pleasant to meet. Awareness and understanding of oneself with all its open and hidden advantages and disadvantages is a difficult path to the development of "self." Meeting with the "shadow" is often unpleasant, causes a lot of negative emotions, sometimes leads to the inclusion of methods of psychological protection such as "squeezing," "forgetting", etc.

The world faces with its old archetype of "shadow" through manifestations of negative acts, in particular, terrorism, violence, at the state level isolationism, separatism. The policy of interculturalism and communitarianism that was popular in the twentieth century has returned by the renaissance of nationalism. What is it, like not meeting with the shadow before forming of "self" and realizing of its new role in the world?

In the philosophical sense, such phenomena are well understood by the French sociologist M. Maffesoli, who identified these manifestations by the word "tribalism" that arises from the need for unity in certain traditions, common feelings, myths that exist in certain areas of social psychology, instead of the imposed values, rules, and norms of life.

The phenomenon is characteristic of large multinational societies, but also for the forms of political system that are being introduced to replace the traditional society. As Michelle Maffesoli writes "it is this proximity that gives meaning to what is called the "divine social'. It has nothing to do with any dogmas or official regulations, and once again clings to that 'pagan string' in the soul of a man, which, no matter how unpleasant it was to hear the historian, never completely ceased to sound in the people" [5].

For Ukraine, which has been in a situation of becoming of a new civilization form of its existence, the role of the "shadow," according to the Ukrainian philosopher Vakhtang Kebuladze, is played by Russia, which itself is not fully civilized, as it is understood in the European context, but only plays the role of the shadow.

At the same time, "the shadow is deprived of strength, it is capable only of violence, which at the end will deprive the force of the person who applies violence" [6].

The individual unconscious, according to K. Jung, is depicted in Figure 1.

The archetype of "self" is the center of the individual unconscious, means the attainment of inner harmony, goodness. It unites in itself all archetypes, as defined by Jung, the archetype of Self is "God in us," an awareness of ourselves as an omnipotent being. It unites the conscious and the unconscious, brings it to the integrity and describes the person himself, reflects the structured image of the psyche, harmony, mental equilibrium [8]. The formation of "self" is a difficult and long process, not every person comes to its realization. Likewise, the collective unconscious of the nation, or the state, passing the path of formation in the historical process, has to pass all stages of development from Anima to the Self and the Logos, or "Uroboros", which in fact is the main archetypal reflection of a strong and stable state. 


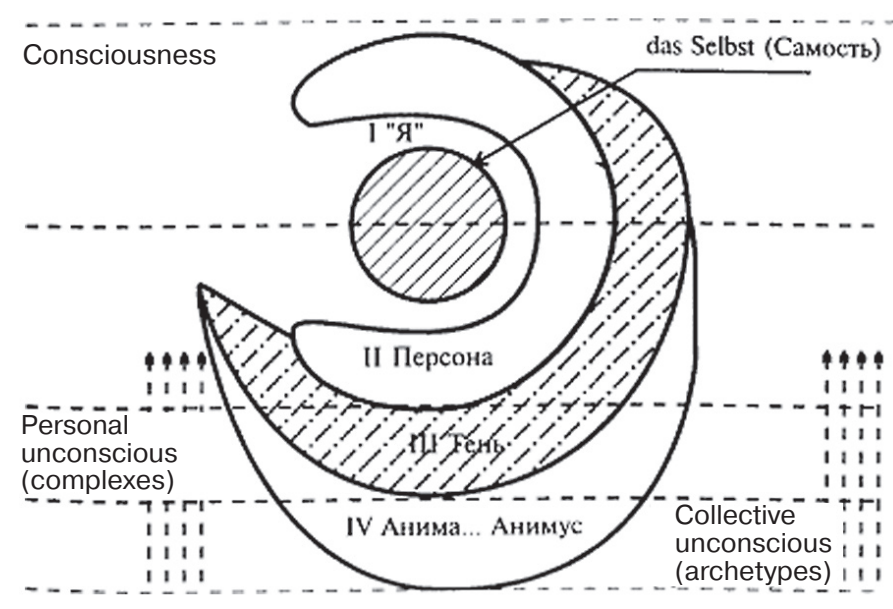

Fig. 1. Structure of personality according to K. Jung [7]

In the Modern period, the stability and effectiveness of the state was characterized by its institutions that actively influenced society, personified power and strength, and had the exclusive right to violence [9]. At the same time, in transition countries, democratic institutions have not become so strong and developed that democracy is consolidated as an irreversible form of government.

Some regimes have become semidemocratic (hybrid democracies), or purely autocratic, as demonstrated to us, in particular, the countries of the former Soviet Union (Russia, Kazakhstan, Turkmenistan). We can assume that in these countries, the connection between rational and irrational is stronger than in countries that have gone through this path for many years and consolidated in their established democracies. It is similar to the connection of the conscious and unconscious in the formation of the individual. Therefore, it is almost impossible to add new values if they do not exist in archetypal subconscious nature, cul- ture, national codes. In Ukraine, for example, the level of political participation grows faster than organization, an ability to unite. As mobilization and political participation in our country are high, and the level of organization and institutionalization is low, between them there is a conflict that manifests itself in the lack of preparedness of the masses to manage [10, p. 64].

The postmodern and informational society have made adjustments to the relationship between archetypes and institutions and the vector has changed, due to the influence of the social that is based on the individual and on the institution. This leads to the hybrid distortion of the very concept of the state as a device of violence and pressure.

He ceases to be sacred and decisive in human life. The society through the organizations of public pressure, individual activity through technology becomes more influential and changes state-power relations. Communicative technologies in the postmodern era serve as an instrument that changes and shapes government institutions in 
the state. At the same time, it becomes a threatening factor for democracy as a form of government and its values.

Political science until the middle of 90's of the twentieth century believed that after the collapse of the USSR, there will be a rapid formation of new countries, where democracy will become a real form of government, and liberal values will lead to a general social and interstate world consensus. History has made its adjustments because not all developing countries become democratic, but because of the emergence of communicative and digital technologies, the violation of the world order since the Second World War, the formation of a world of true truth, and democracy itself is in jeopardy.

The term "wave of democratization", which refers to certain completed cycles of transition to democracy, $\mathrm{S}$. Huntington introduces in his book "The Third Wave at the End of the $20^{\text {th }}$ Century" in 1991. He gives the following periodization: the first rise of the wave (1828-1926), the first recession (1922-1942), the second rise (1943-1962), the second recession (1958-1975), the third rise (1974 and continues to this day) [11].

One of the stable expressions that characterize the process of the establishment of democracy in the twentieth century in post-Soviet countries is the notion of "democratic transit". The term "transit" in the English translation "transitional" means transitory. Consequently, the notions of "democratic transit" and "democratic transition" are identical. The term "democratic transit" is used to mean the transition from a totalitarian or authoritarian political regime to a democratic one.
Democratic transit is an unfinished dynamic, temporary process, in which continuous adaptation is carried out, the approach of existing institutions of public authority and institutions of the civil society to perfect ideas about modern institutions and the ideal society of the democratic political regime, which is constantly updated. It is an unclear period of time between the collapse of the totalitarian regime and the moment when the levers of power pass under full control of the democratic regime that changes it. This period is usually completed, M. Baranov is convinced, when democracy gives itself to legitimate institutions and a constitution, when democratic leaders have secured their rule, recognized by the army and nomenclature, which makes possible the peaceful transition of power [12, p. 115]. However, under certain conditions, the process of democratic transit may return to an authoritarian or totalitarian regime. Consequently, G. O'Donnell [13], W. Merkel and A. Croasan [14] argue that in countries where predominantly non-civic types of political culture dominate, democratization processes last for a long time and lead to the emergence of "inferior" or "defective" democracies in which there are democratic institutions, but the essence of power and social relations remains authoritarian.

Postcommunist transformations represent a new wave, however, the trajectories and results of postcommunist transformations are different. D. Rastou [15], G. O'Donnell, F. Schmitter [16], A. Pesvorsky [17] define the following phases of democratic transit and determine the order (see Table). 
The phases of transition to democracy [18, c. 96]

\begin{tabular}{|l|l|l|l|}
\hline \multicolumn{1}{|c|}{ Scientist } & \multicolumn{1}{c|}{ The first phase } & The second phase & \multicolumn{1}{c|}{ The third phase } \\
\hline $\begin{array}{l}\text { According } \\
\text { to D. Rastou }\end{array}$ & Preparatory phase & $\begin{array}{l}\text { Decision making } \\
\text { phase }\end{array}$ & The addictive phase \\
\hline $\begin{array}{l}\text { According } \\
\text { to G. O'Donnell } \\
\text { and F. Schmitter }\end{array}$ & Liberalization & Democratization & Socialization \\
\hline $\begin{array}{l}\text { According } \\
\text { to A. Pshevorsky }\end{array}$ & Liberalization & \multicolumn{2}{|c|}{ Democratization } \\
\cline { 3 - 4 } & & Release & Constitution \\
\hline
\end{tabular}

At the first stage decentralization of power takes place, the appearance of pluralism of thoughts, conflicts between supporters of the old government and the opposition is marked.

The second stage is characterized by the participation of the civil society in the decision-making process, which becomes possible as a result of the constitutional formulation of democratic institutions.

At the third stage, the activity of the civil society that acquires civilized forms increases and manifests itself in the establishment of public control, the fight against corruption and bureaucracy.

The fourth stage is the formation of a legal state through the assimilation and introduction of new norms and values by citizens of the country, consolidation of the society. Institutions of the civil society are grouped around state institutions.

According to O. Skrypnyk at certain stages that are connected with the transition from totalitarian and authoritarian political regimes, elements of struggle and confrontation between the state and the civil society are traced. This is natural, because the civil society is freed from under the state authority. Secondly, in this case it is correct to speak about the struggle not between the state and the civil society in general, but only between the civil society and a certain type of organization of state power [19, p. 432].

S. Huntington and his followers believe the main source of democratic transit is the conflict between the inclusion of the population in the active life of the society and the institutions of public authority. Mass activity in transitional periods outstrips the development of political institutions of the society. As a result, chaos and instability arise, conflicts that hinder the formation of democratic institutions in society. At the same time, postmodern values finally change priorities, giving preference to self-expression, the quality of human life over economic efficiency, individual over collective and transforms static social norms into a dynamic network [20, p. 9].

New technologies, possibilities of the information world, crisis phenomena, natural disasters, expansion of peculiarities of influences on consciousness form new social phenomena of mutual relations in the society and create conditions for development and positive changes, for new challenges and crises.

G. Casper and M. Taylor determine the role of conflict in political tension and the development of a stable de- 
mocracy. According to the authors, the more difficult and hard the democratization takes place, and the more negotiations between its subjects are conducted, the stronger will be democracy itself [21, p. 50].

Democracies that emerge from such a "light process" do not show signs of consolidation and can return to authoritarianism. According to researches of H. Linz, the collapse of democratized regimes is due to the low professionalism of new democrats and the emergence of unsolvable problems and crises resulting from this; the presence of political violence in the process of the collapse of democracies; a gradual abandonment of the conquest of democracy and authoritarian tendencies in the leadership of new democratic institutions; confrontation of the institutions of parliamentarism and presidency [22].

All theories of democratic transit are based on rational thinking that is inherent in the industrial society and exists in the paradigm of the theory of world systems of I. Valerstain and the various concepts of globalization, which were based on the economic concept of global capitalism. Approaches of development of the industry and the formation of profit and utility became the basis of the class of consumers.

The theory of I. Valerstein is now complemented by new approaches [23], in which, in particular, are distinguished of the division of the world's countries into the nucleus of the world system, countries of semi-periphery and countries of periphery. The gap in economic, political, and social development between these countries becomes a menacing source of international instability and a threat to humanity. Democra- tic institutions in different countries have a pronounced national character and are formed under the influence of the mentality of an nation and its habits of governance, but where violence is often used, they become accustomed to it, as stated by E. Durkheim [24]. At the same time, it should be noted the global nature of transit processes.

A. Melville, answering the question about the causes of various trajectories and the results of post-communist transformations, points to the following factors: presence or absence of democratic experience; the peculiarities of the external environment as a factor that supports or hinders to internal transformations; the state of socioeconomic, political, cultural and other spheres at the starting points of political transformation; the process of decay of authoritarian power structures; the principles of changing political and economic elites; the specific of the new political institutions and the ways of their construction; the tactics of political actors [25, p. 73-74].

The trend of the convergence of the civil society and government structures is characteristic of stable democracies. The civil society arises as a result of complications in the state as an effective system that will optimize democratic processes. Democracy rests on a strong civil society that presses on the institutions that oppose it. We are currently seeing this process in Ukraine.

Relations between the government and the civil society are different in different political regimes, but in transitional periods, in particular during the period of democratic transit, one can observe a frequent change of types of these relationships, namely: ignor- 
ing, confrontation, competition, consistency (consensus). In the period of democratic transit there is a high level of social activity and conflict in society. Figure 2 shows the spectrum of relations between public authorities and civil society institutions during the period of democratic transit.

Ignoring - abandoning attention, neglecting the views of organizations of the civil society by the state and rejection of the activities of the authorities by the institutions of the civil society, in psychology - a form of psychological protection, which controls the information on the source of influence by limiting the volume of such information or its distorted perception. Ignoring accompany hidden conflicts.

Confrontation - transformational processes in the society lead to a disturbance of balance in the relations of the public authority and the civil society, confrontation, resulting in the emergence of conflicts.

Competition - (in French - confrontation), confrontation, opposition, collision of social systems, class interests, beliefs (for instance, confrontation of policy, military confrontation, confrontation of views).

Coherence (consensus) is cooperation in problem solving in which both parties act openly and transparently; public control over government activities and control by the authorities, the phase of establishing and adapting of democratic structures, institutions and norms that are partly or fully recognized by the civil society as legitimate.

The main task of the authorities and organizations of the civil society in the context of democratic transit is to facilitate the process of democratization. However, the transfer of finished models of institutions and models of

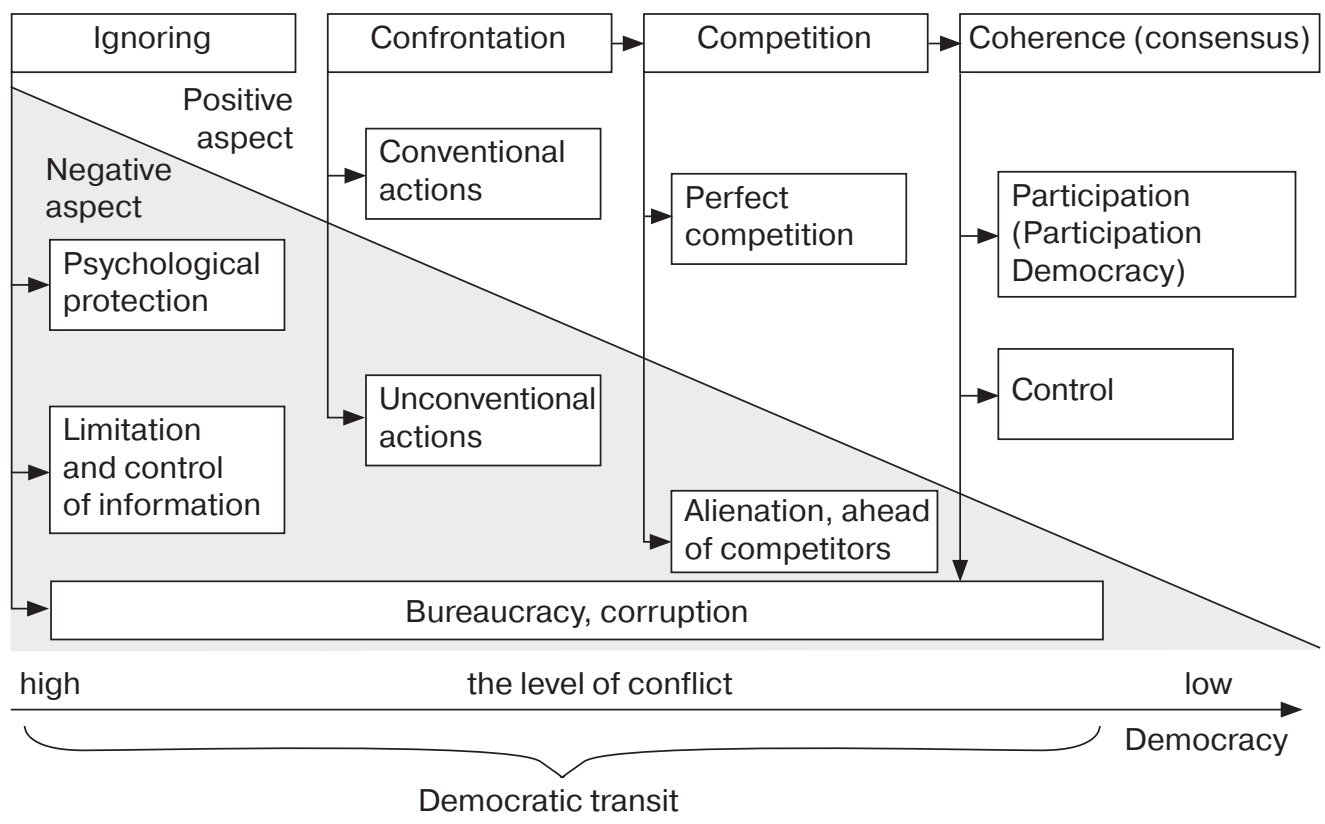

Fig. 2. The sequence of democratization of public relations authorities and institutions of the civil society in the conditions of democratic transit [26, p. 7] 
relationships can also lead to conflict situations in the society.

Models of relations between government and institutions of the civil society depend on the level of development of the civil society and its institutions, on the one hand, and the democracy of the state, in which the branches of power operate in a balanced manner. Confrontation in the relations between public authorities and institutions of the civil society is an indicator of the ineffectiveness of the public administration and the system of the civil society.

With the establishment of democratic institutions, the period of democratic transition, which goes into democracy, ends. Under unfavorable conditions, the process of democratic transit ends with the establishment of authoritarian and totalitarian regimes.

According to the American futurist E. Toffler, the transition from an industrial society to a "computer-information civilization" has the following characteristics: information technology; disassociated society in which classes lose their meaning; anticipated democracy, which ensures citizens' participation in the society; transnational institutes, decisive global problems of the present.

We can state that the world is now fully integrated into a new type of the society. And in such society it becomes impossible to mobilize the masses and, as a result, "we have a configurable society, a society where thousands of minorities, many of which are temporary, create new transitional models, rarely combining $51 \%$ consensus on serious problems. The promotion of the civilization of the third Wave, thus, weakens the legitimacy itself of many existing governments" [27, p. 661-662].

Under the conditions of the information society, there is another type of relationship between the authorities and the civil society, which can be called imitation, which weakens the power itself, because it reduces the trust both to it and to the institutions of the civil society. People no longer see the need for self-organization.

The conclusions and perspectives of further research are the need to analyze the modern world and the processes that occur in it, using an interdisciplinary view and archetypal methodology, as the convergence of social and individual mental is intensifying. The processes of state-building that take place in Ukraine today have become a consequence, a logical manifestation of the archetype of "self-organization" under conditions of ineffective, corrupt, copied from the Soviet forms of state power. In terms of traditionalism, they can be called chaos, from the point of view of the post-industrial informational world, which gradually turns into a networked society, is the formation of a new management system based on synergistic processes, but cannot be arranged in the traditional sense of the concept. But it is impossible to say that transformation will result in the establishment of a stable and developed democratic model on liberal economic principles, since these ideas and values themselves fall under civilizational changes, and authoritarian and totalitarian traditions remain very strong in the archetypes of the population in Ukraine. Involving citizens in policy implementation becomes a trend of the Ukrainian political system, but 
resistance of the system also remains strong.

\section{REFERENCES}

1. Donchenko E. A. (2005), Fraktal'naya psykholohyya (Dohlubynnye osnovanyya yndyvydual'noy y sotsyetal'noy zhyzny) [Fractal Psychology (Submarine Foundations of Individual and Social Life)], Znannya, Kyiv, Ukraine.

2. Neumann E. (2012), Velykaya mat' [Great Mother], available at: http:// castalia.ru/posledovateli-yungaperevody/731-erih-noymann-velikaya-mat-glava-pervaya-strukturaarhetipa.html.

3. Donchenko E. A. (2005), Fraktal'naya psykholohyya (Dohlubynnye osnovanyya yndyvydual'noy y sotsyetal'noy zhyzny) [Fractal Psychology (Submarine Foundations of Individual and Social Life)], Znannya, Kyiv, Ukraine.

4. Sibiryakov S. (2013), Social media as an environment of archetypal influence on the mass consciousness, Publichne upravlinnya: teoriya ta praktyka: zbirnyk naukovykh prats' Asotsiatsiyi doktoriv nauk z derzhavnoho upravlinnya, vol. 1 (13), p. 202-210.

5. Maffesoli M. (1991), The awakening of the world or the divine social, SOCIOLOGOS Progress, Moscow, Russia, pp. 274-283, available at: http://www.imaginaire.ru/node/117

6. Kebuladze V. (2014), Intelligentsia contra intellectuals, Filosofs'ka dumka, vol. 2, available at: http://journal.philosophy.ua/sites/default/files/library/ files.pdf

7. Jung's personality structure, available at : https://sites.google.com/site/tohabiblio/the-team/analiticeskaa-teoria-unga/struktura-licnosti-po-ungu

8. Lashkina M. (2017), Communicative component of conflict in the modern world: the birth of the archetype of the selfness, Public management : collec- tion, vol. 3 (8), June 2017, p. 167-178, DP "Vydavnychyy dim "Personal", Kyiv, Ukraine.

9. Afonin E., Sushi O., Usachenko L. (2011), Patterns and Peculiarities of Social Transformation Processes in Ukraine, Ukrayins'kyy sotsium, vol. 4, p. 7-30, available at : http://www. ukr-socium.org.ua/stok/Aktual/ Afonin 4 2011.pdf

10. Radchenko O. (2007), Political regime in Ukraine and the theory of modernization: the choice of the path of democratization, Aktual'ni problemy derzhavnoho upravlinnya : zb. nauk. pr. Odes'koho rehional'noho instytutu derzhavnoho upravlinnya, vol. 1 (29), p. 59-64, Vyd-vo ORIDU NADU, Odesa, Ukraine.

11. Huntington S. (2003), Tret'ya volna. Demokratyzatsyya v kontse XX veka [Third wave. Democratization at the end of the twentieth century], available at : http://www.archipelag.ru/ download/book/text_pdf/hantington_wave.pdf

12. Baranov N. (2006), Transformatsyy sovremennoy demokratyy [Transformation of Modern Democracy], The Baltic State University, St. Petersburg, Russia.

13. O'Donnell G. (1994), Delegative democracy, Journal of Democracy. January, vol. 5, № 1, P. 56.

14. Merkel V. (2002), Formal and Informal Institutions in Defective Democracies, Polys, vol. 1, p. 7-17.

15. Rustow D. A. (1970), Transitions to Democracy : Toward a Dynamic Model, Comparative Politics, April, vol. 3, P. 341-342, 345 .

16. O'Donnell G., Shmitter Ph. (1986), Transition from Authoritarian Rule, Tentative Conclusions About Uncertain Democracies, Baltimor.

17. Pshevorsky A. (1999), Demokratyya y rynok. Polytycheskye y ékonomycheskye reformy v Vostochnoy Evrope 
y Latynskoy Ameryke [Democracy and the market. Political and Economic Reforms in Eastern Europe and Latin America], Rosspén, Moscow, Russia.

18. Gavrilyuk G. I. (2008), "Defective Democracy" and Cognitive Possibilities of the Transitological Paradigm, Visnyk Kharkivs'koho natsional'noho universytetu imeni V. N. Karazina, vol. 825, № 13, p. 94-101.

19. Skrypnjuk O. (2000), Sotsial'na, pravova derzhava $\mathrm{v}$ Ukrayini : problemy teoriyi i praktyky [Social and lawful state in Ukraine: problems of theory and practice], Instytut derzhavy i prava im. V. M. Korets'koho NAN Ukrayiny, Kyiv, Ukraine.

20. Afonin E., Sushi O., Usachenko L. (2011), Patterns and Peculiarities of Social Transformation Processes in Ukraine, Ukrayins'kyy sotsium, vol. 4, p. 7-30, available at : http://www. ukr-socium.org.ua/stok/Aktual/ Afonin_4_2011.pdf.

21. Casper G., Tailor M. (1966), Negotiating Democracy. Transition From Authoritarian Rule, University of Pittsburgh Press.

22. Linz J.J. (1990), Transitions to Democracy, The Washington Quarterly, Summer, vol. 3.

23. Wallerstein I. (2001), Analysis of world systems and the situation in the modern world, Yzd-vo "Unyversal'naya knyha”, St. Petersburg, Russia.

24. Durkheim E. (1995), The Elementary Forms of Religious Life, trans, Karen Fields, New York: Free Press.

25. Melvil A. (2004), On the Trajectories of Post-Communist Transformations, Polis, vol. 2, p. 64-75.

26. Bielska T. (2010), Relations between public authorities and civil society institutions in the conditions of democratic transit; Abstract of Ph.D. dissertation, Public Administration, National Academy for Public Administration under the President of
Ukraine, Kharkiv. region in-t state government, Kharkiv, Ukraine, P. 7.

27. Toffler E. (2002), Third wave, LLC "Publishing AST", Moscow, Russia.

\section{СПИСОК ВИКОРИСТАНИХ ДЖЕРЕЛ}

1. Донченко E. А. Фрактальная психология (Доглубинные основания индивидуальной и социетальной жизни) / Е. А. Донченко. - К. : Знання, 2005. - 323 c.

2. Нойманн Э. Великая мать [Электронный ресурс] / Э. Нойманн. 2012. - Режим доступа: http:// castalia.ru/posledovateli-yungaperevody / 731 - erih-noymannvelikaya-mat-glava-pervayastruktura-arhetipa.html

3. Донченко E. А. Фрактальная психология (Доглубинные основания индивидуальной и социетальной жизни) / Е. А. Донченко. - К. : Знання, 2005. - 323 c.

4. Сибиряков С. Соціальні медіа як середовище архетипного впливу на масову свідомість / С. Сибиряков // Публічне управління: теорія та практика: зб. наук. пр. Асоціації докторів наук з державного управління. - Х.: ДокНаукДержУПр, 2013. Вип. № 1 (13). - С. 202-210.

5. Маффесоли М. Околдованность мира или божественное социальное [Электронный ресурс] / М. Маффесоли // СОЦИО-ЛОГОС. - М. : Прогресс, 1991. - С. 274-283. - Peжим доступа : http://www.imaginaire. $\mathrm{ru} /$ node $/ 117$

6. Кебуладзе В. Інтелектуали contra iнтелігенція [Електронний ресурс] / В. Кебуладзе // Філософська думка. - 2014. - № 2. - Режим доступу: http://journal.philosophy.ua/sites/ default/files/library/files.pdf

7. Структура личности по Юнгу [Электронный ресурс]. - Режим до- 
ступа : https://sites.google.com/site/ tohabiblio/the-team/analiticeskaateoria-unga/struktura-licnosti-poungu

8. Lashkina M. "Communicative component of conflict in the modern world: the birth of the archetype of the selfness" / Public management : collection. - № 3 (8). - June 2017 (Special edition). - Kyiv : ДП “Вид. дім “Персонал”, 2017. - С. 167-178.

9. Закономірності та особливості суспільно-трансформаційних процесів в Україні [Електронний ресурс] / Е. А. Афонін, О. В. Суший, Л. М. Усаченко // Український соціум. - 2011. - № 4. - С. 7-30. Режим доступу : http://www. ukr-socium.org.ua/stok/Aktual/ Afonin_4_2011.pdf

10. Радченко О. В. Політичний режим в Україні та теорії модернізації: вибір шляху демократизації / О. В. Радченко // Актуальні проблеми державного управління : зб. наук. пр. Одеського регіон. ін-ту держ. упр. Одеса. : Вид-во ОРІДУ НАДУ, 2007. - Вип 1 (29). - С. 59-64.

11. Хантингтон $C$. Третья волна. Демократизация в конце XX века [Электронный ресурс] / С. Хантингтон; [пер. с англ.]. - Режим доступа : http://www.archipelag.ru/download/ book/text_pdf/hantington_wave.pdf

12. Баранов Н. А. Трансформации современной демократии / Н. А. Баранов. - СПб. : Балт. гос. техн. ун-т, 2006. -215 c.

13. O’Donnell G. "Delegative democracy", Journal of Democracy. - January 1994. - Vol. 5, № 1. - P. 56.

14. Меркель В. Формальные и неформальные институты в дефектных демократиях / В. Меркель, А. Круассан // Полис. - 2002. - № 1. C. 7-17.

15. Rustow D. A. Transitions to Democracy: Toward a Dynamic Model. Com- parative Politics / D. A. Rustow. April 1970. - № 3. - P. 341-342, 345.

16. O’Donnell G., Shmitter Ph. Transition from Authoritarian Rule. Tentative Conclusions About Uncertain Democracies. Baltimor, 1986.

17. Пшеворсъкий А. Демократия и рынок. Политические и экономические реформы в Восточной Европе и Латинской Америке / А. Пшеворский; [пер. с англ.; под ред. и с предисл. В. А. Бажанова]. - М. : Росспэн, 1999. - $319 \mathrm{c}$.

18. Гаврилюк Г. I. “Дефектні демократіі” та пізнавальні можливості транзитологічної парадигми / Г. І. Гаврилюк // Вісн. Харків. нац. ун-ту ім. В. Н. Каразіна. - 2008. - № 825. Вип. 13. - С. 94-101. - (Серія "Питання політологіі”).

19. Скрипнюк О. В. Соціальна, правова держава в Україні : проблеми теорії і практики : монографія. - К. : Інститут держави і права ім. В. М. Корецького НАН України, 2000. $600 \mathrm{c}$.

20. Закономірності та особливості суспільно-трансформаційних процесів в Україні [Електронний ресурс] / E. А. Афонін, О. В. Суший, Л. М. Усаченко // Український соціум. - 2011. - № 4. - С. 7-30. Режим доступу : http://www.ukr-soc i u m.org.ua/s tok/Aktual/ Afonin_4_2011.pdf

21. Casper G., Tailor M. Negotiating Democracy. Transition From Authoritarian Rule. - University of Pittsburgh Press, 1966.

22. Linz J.J. Transitions to Democracy. The Washington Quarterly, Summer 1990. - № 3.

23. Валлерстайн И. Анализ мировых систем и ситуация в современном мире [пер. с англ. П. М. Кудюкина] / И. Валлерстайн ; под ред. Б. Ю. Кагарлицкий. - СПб. : Универсальная кн., 2001. - 416 c. 
24. Durkheim E. The Elementary Forms of Religious Life, trans. Karen Fields. New York: Free Press, 1995.

25. Мельвиль А. Ю. О траекториях посткоммунистических трансформаций / А. Ю. Мельвиль // Полис. 2004. - № 2. - С. 64-75.

26. Бєльська T. Взаємовідносини органів публічної влади та інститутів громадянського суспільства в умо- вах демократичного транзиту : автореф. дис. ... канд. наук з держ. упр. : спец. 25.00.01 / Т. В. Бєльська; Нац. акад. держ. упр. при Президентові України, Харк. регіон. ін-т держ. упр. - Х., 2010. - 19 с.

27. Тоффлер Э. Третья волна: пер. с англ. / Э. Тоффлер. - М. : ООО “Изд-во АСТ", 2002. - 776, [8] с. (Philosophy). 